\title{
Aetio-Pathological Studies of Digestive and Respiratory Affections Affecting Kids
}

\author{
Sushma*, V. Nehra, B. L. Jangir and V. Sharma \\ Department of Veterinary Pathology, College of Veterinary Sciences, Lala Lajpat Rai \\ University of Veterinary and Animal Sciences, Hisar-125 004, Haryana, India \\ *Corresponding author
}

\begin{abstract}
A B S T R A C T
Aetio-pathological studies of digestive and respiratory affections were undertaken on ten

\section{Keywords}

Eimeria spp., In-vitro drug sensitivity, Kids, mortality, Pneumoenteritis

Article Info

Accepted:

04 April 2018

Available Online:

10 May 2018 carcasses of kids of age below six months received for post mortem examination to the Department of Veterinary Pathology, Lala Lajpat Rai University of Veterinary and Animal Sciences (LUVAS), Hisar during a period of seven months i.e. from September, 2015 to March, 2016. Study revealed that maximum mortality was in kids of 1 to 3 months of age. Sex-wise mortality was more in males as compared to females. A system-wise cause of mortality was highest due to combined involvement of digestive as well as respiratory systems followed by involvement of digestive and respiratory system alone. Bacteriological study of different samples collected from carcasses of kids revealed that presence of E. coli, Proteus spp., Klebsiella spp. and Salmonella spp. Maximum number of bacterial species were isolated from intestine followed by lungs and heart blood. The results of in-vitro drug sensitivity testing revealed that most of bacterial strains were sensitive to gentamycin and resistant to tetracycline. Examination of faecal samples of dead and diarrhoeic kids revealed major infestation of Eimeria spp.
\end{abstract}

\section{Introduction}

In most region of our country, goats are mainly reared for meat and milk purposes. Two reasons for the goats' ability to survive in some of the most inhospitable regions of the world are their exceptional tolerance to heat stress (Norman, 1991) and ability to grow on poor quality feed. Therefore, goat production is equally suited to marginal farming areas, small farms or large-scale production in the tropics and sub-tropics. While goats are generally considered hardy animals and in many situations receive little medical care, they are subject to a number of diseases. Among the conditions affecting goats are respiratory diseases including pneumonia, foot rot, internal parasites, pregnancy toxosis and feed toxicity. Goats can become infected with various diseases, such as colibacillosis, salmonellosis, peste des Petits Ruminants (PPR), enterotoxaemia, foot-and-mouth disease, caprine arthritis encephalitis, caseous lymphadenitis, pinkeye, mastitis, tuberculosis and brucellosis. Parasitic gastro-enteritis leads to a serious health threat with a limitation to the productivity of small ruminants due to the associated morbidity, mortality, cost of 
treatment and prophylaxis (Nwosu et al., 2007). Goats have numerous internal parasites and one of the most important is the coccidian species (Dai et al., 2006). For the prevention and control of mortality in kids, a study was planned on the aetio-pathological aspects of the disease conditions causing mortality in kids with particular reference to digestive and respiratory system disorders so that adequate therapeutic and preventive measures can be taken or advised to prevent further losses to farmers/farm personnel.

\section{Materials and Methods}

Ten carcasses of kids aged below six months were brought to the post mortem hall of the Department of Veterinary Pathology, LUVAS, Hisar during period from September, 2015 to March, 2016 for necropsy examination. Following parameters were studied:

\section{Postmortem examination and pathological study}

A detailed postmortem examination was conducted immediately on arrival of the carcass. Representative and appropriate tissue pieces from intestine, part of stomach, liver, lung, trachea, heart and mesenteric lymph nodes were collected in $10 \%$ buffered formalin and were subsequently processed for histopathological studies. The formalin fixed tissues were processed for paraffin embedding technique. The section were cut at the thickness of 3-4 $\mu$ and stained with $\mathrm{H}$ \& $\mathrm{E}$ stain (Luna, 1968).

\section{Bacteriological study}

At necropsy, materials for bacteriological studies were collected aseptically in sterile containers. Isolation of organisms was attempted from the heart blood, lung, trachea, and intestinal contents. The collected samples were put in nutrient broth or buffered peptone water and incubated at $37^{\circ} \mathrm{C}$ for $24 \mathrm{~h}$. The next day after collection of the samples, $1 \mathrm{ml}$ of culture from buffered peptone water was transferred to selenite broth and incubated at $37^{\circ} \mathrm{C}$ for 24 to $48 \mathrm{~h}$, while those collected in nutrient broth were inoculated on Nutrient agar (NA) and Mac Conkey's Lactose agar (MLA) plates and incubated at $37^{\circ} \mathrm{C}$ for $24-48$ h. From MLA plate, lactose fermenting colonies were taken, inoculated on Eosin Methylene Blue (EMB) agar and incubated at $37^{\circ} \mathrm{C}$ for $24 \mathrm{~h}$ and the isolates were stored in maintenance medium. From NA plates, golden orange coloured, round, opaque and luxuriant colonies developed were selected and inoculated on Baired Parker agar (BP) and incubated at $37^{\circ} \mathrm{C}$ for $24-48 \mathrm{~h}$. From BP agar, the black coloured colonies were selected and stored in maintenance medium.

The culture from selenite broth was streaked on Brilliant Green agar (BGA) and incubated at $37^{\circ} \mathrm{C}$ for $24 \mathrm{~h}$. The plates were observed for colonies after incubation. From BGA plate, pinkish white colonies were taken and inoculated on Xylose-Lysine Deoxycholate (XLD) agar and incubated at $37^{\circ} \mathrm{C}$ for $24 \mathrm{~h}$ and the isolates were stored in maintenance medium. Identification of all isolates was done following the procedure of Cruickshank and McCartney (1965). All bacterial isolates were stained by Gram's staining and examined for their morphological characteristics. Biochemical tests viz. IMViC (Indole, methyl red, Voges-Proskauer and citrate utilization test), sugar fermentation tests, nitrate reduction test, urease tests, $\mathrm{H}_{2} \mathrm{~S}$ production test on triple sugar iron medium, and catalase test were also performed.

\section{In-vitro drug sensitivity testing}

Different isolated bacterial strains were subjected to in-vitro drug sensitivity testing using antimicrobials by the disc diffusion method as suggested by Bauer et al., (1966). 
With the help of a platinum loop, small amount of growth from at least three isolated colonies of the organisms were transferred into a tube of trypticase soya broth and incubated for two to five hours at $37^{\circ} \mathrm{C}$ so as to obtain a turbidity, equivalent to that obtained by adding $0.5 \mathrm{ml}$ of $0.048 \mathrm{M} \mathrm{BaCl}_{2}(1.175 \%$ $\left.\mathrm{BaCl}_{2}, 2 \mathrm{H}_{2} \mathrm{O}\right)$ to $99.5 \mathrm{ml}$ of $0.36 \mathrm{M} \mathrm{NH}_{2} \mathrm{SO}_{4}$ $(1 \% \mathrm{v} / \mathrm{v})$. The broth culture was then evenly spread by smearing over the surface of Mueller Hinton agar plates. Different antibiotic discs of standard concentrations were then used. The plates were then incubated at $37^{\circ} \mathrm{C}$ for $18-24 \mathrm{~h}$ and observed for sensitivity by measuring the zones of inhibition. Results were noted as sensitive (S) and resistant (R) on the basis of the table provided by the manufacturer (Himedia) for zone size interpretation.

\section{Parasitological studies}

A total of 18 faecal samples were collected i.e. eight from carcasses of kids received for post mortem examination and ten from diarrheic kids of the organized farm of the University and Central Sheep Breeding Farm, Hisar. Examination of these faecal samples was performed as per the method of Soulsby (1982) by floatation and sedimentation techniques.

\section{Results and Discussion}

As per the information provided and from the post mortem requisition form it was noticed that most of the kids had died suddenly without showing any clinical signs and symptoms, whereas others were being treated for diarrhoea, dehydration and weakness. The mortality pattern according to age, sex, system-wise causes of death/mortality along with different bacterial species isolated from various samples and faecal examination of dead as well as diarrhoeic kids is given in Table 1. The proposed study starting from
September, 2015 to March, 2016 of kids revealed that maximum age-wise mortality was in age group of 1 to 3 months followed by upto 1 month and no mortality were seen in age group of 3 to 6 months. These findings were supported by Ershaduzzaman et al., (2007) and Dohare et al., (2013) as they reported that higher mortality in kids was in 0 to 3 months of age. However, RamirezBribiesca et al., (2001) reported maximum mortality during 8 to 90 days of life in kids. Sex-wise mortality was more in male as compared to female kids. These finding were supported by Malik et al., (1990) as they reported that mortality rates were higher in male as compared to female kids. However, Husain et al., (1995), Chowdhury et al., (2002) and Ershaduzzaman et al., (2007) reported higher mortality in female than male kids. Honhold (2001) found no significant differences in mortality between the sexes. System-wise mortality was highest due to combined involvement of digestive as well as respiratory systems followed by involvement of digestive and respiratory system alone. Gastritis, enteritis, pneumo-enteritis, hepatitis and pneumonia were the main conditions encountered in kids. Sharma et al., (2007); Alam et al., (2008); Sabapara and Deshpande (2010) and Dohare et al., (2013) reported that major causes of mortality was enteritis and pneumonia.

Grossly, intestine showed congestion, haemorrhages and presence of catarrhal exudate. Mesenteric lymph nodes were found enlarged. Liver revealed congestion, firmness and induration. Gall bladder was fully distended. Lungs showed congestion and consolidation. Trachea showed presence of whitish frothy exudate in lumen. Heart disclosed presence of haemorrhages on epicardium. Kidney revealed congestion and pale necrotic areas. Spleen revealed petechial haemorrhages. There was distension in urinary bladder due to accumulation of urine. 
Hydrothorax along with presence of serosenguinous fluid and inflammation of umbilicus with accumulation of pus was also observed. Almost similar observations regarding gross lesions were also reported by Abou-Zaid et al., (2000) in kids.

Histopathologically, intestine exhibited catarrhal enteritis characterised by goblet cell hyperplasia along with infiltration of leucocytes thereby completely replacing the mucosal glands and goblet cell hyperplasia showing blue coloured muco substances were observed in PAS- Alcian blue staining. Other changes noticed were congestion and haemorrhages in mucosa, necrosed villi epithelium and serositis. Liver revealed hepatitis characterised by focal area of necrosis along with leucocytic cells infiltration. Few cases were showing hepatitis characterised by atrophy of hepatocytes in parenchyma, leucocytic cells infiltration and hydropic changes in hepatocytes. Apart from these, there was congestion in blood vessels along with telengiectasis. Similar observations were reported by Khillare et al., (2014) and Patel et al., (2015) in kids. Lungs showed serous pneumonia characterised by presence of serous fluid in alveoli along with infiltration of leucocytes and emphysema. Presence of rod shaped Gram negative bacteria (bright red coloured) was observed after Taylor's staining. Other changes observed were haemorrhages in parenchyma, congestion and peribronchiolar lymphoid aggregation. Apart from these, atelectasis was also observed. In trachea, there was mild tracheitis characterized by presence of mild haemorrhages along with infiltration of leucocytes in few cases. Similar observations were reported by Patel et al., (2015) in kids. Kidney disclosed presence of focal interstitial nephritis characterised by infiltration of leucocytes, degeneration of tubules, haemorrhages, congestion in blood vessels and also in glomeruli capillary and focal area of necrosis was also observed. More or less similar observations were recently reported by Patel et al., (2015). Heart revealed mild myocarditis characterised by presence of mild haemorrhages and congestion along with infiltration of leucocytes at focal areas in some of the cases. Some cases of kids revealed presence of myocarditis characterised by severe infiltration of leucocytes and fragmentation of muscle fibres along with presence of sarcocyst. Myxomatous degeneration, fragmentation of muscle fibres and infiltration of leucocytes were also found in few cases. Apart from these, haemorrhages in epicardium and fatty changes were also observed. Spleen showed severe haemorrhages and haemosiderosis in white pulp, congestion. Haemosiderrosis was also seen after Pearl's staining (Table 2).

Depletion of lymphocytes in white pulp and focal areas of necrosis was also seen in spleen. Mesenteric lymph nodes revealed depletion of lymphocytes along with congestion and hyperplasia of cells. Similar lesions in spleen and mesenteric lymph node have been reported by Som and Bhattacharya (1987) and Patel et al., (2015). Microbiological study of different samples collected from carcasses of kids revealed that presence of E. coli, Proteus spp., Klebsiella spp. and Salmonella spp.

Maximum numbers of bacterial species were isolated from intestine followed by lungs and heart blood. Various other workers (Sharif et al., 2005 and Zaki et al., 2010) have also been reported the isolation of these bacterial species from the carcasses of kids. In vitro drug sensitivity against different bacterial species isolated from different samples collected from carcasses of kids revealed that $E$. coli was found highly sensitive to gentamycin; Salmonella spp. to gentamycin, cefotaxime, streptomycin; Klebsiella spp. to streptomycin; Proteus spp. to gentamycin, amikacin, cefotaxime (Fig. 1-7). 
Table.1 Age, sex and system-wise mortality pattern, different bacterial species isolated from various samples along with faecal examination of dead and diarrhoeic kids

\begin{tabular}{|c|c|c|c|c|c|c|}
\hline \multicolumn{7}{|c|}{ Age and sex-wise mortality in kids } \\
\hline Age groups & $\begin{array}{l}\text { Males } \\
\text { (Number of } \\
\text { cases) }\end{array}$ & $\begin{array}{l}\text { Percentage of age- } \\
\text { wise mortality in } \\
\text { males }\end{array}$ & $\begin{array}{l}\text { Females } \\
\text { (Number of cases) }\end{array}$ & $\begin{array}{l}\text { Percentage of } \\
\text { age-wise } \\
\text { mortality in } \\
\text { females }\end{array}$ & Total & $\begin{array}{l}\text { Percentage of } \\
\text { total age-wise } \\
\text { mortality }\end{array}$ \\
\hline Up to 1 month & 2 & 28.57 & 1 & 50.00 & $\mathbf{0 3}$ & 33.34 \\
\hline 1-3 months & 5 & 71.43 & 1 & 50.00 & 06 & 66.66 \\
\hline 3-6 months & 0 & 00.00 & 0 & 00.00 & 00 & \\
\hline $\begin{array}{l}\text { Total number of sex- } \\
\text { wise mortality }\end{array}$ & $7(77.77 \%)$ & - & $2(22.23 \%)$ & - & \multicolumn{2}{|l|}{$9(100.00 \%)$} \\
\hline \multicolumn{7}{|c|}{ System-wise causes of mortality in kids } \\
\hline $\begin{array}{l}\text { System-wise causes } \\
\text { of mortality }\end{array}$ & $\begin{array}{l}\text { Digestive system } \\
\text { alone }\end{array}$ & $\begin{array}{l}\text { Respiratory } \\
\text { system alone }\end{array}$ & $\begin{array}{l}\text { Combination of } \\
\text { both digestive and } \\
\text { respiratory } \\
\text { systems }\end{array}$ & $\begin{array}{l}\text { Others } \\
\text { systems/ } \\
\text { causes }\end{array}$ & $\begin{array}{l}\text { Putrefied } \\
\text { carcass }\end{array}$ & $\begin{array}{l}\text { Total number of } \\
\text { cases }\end{array}$ \\
\hline $\begin{array}{l}\text { Total number of } \\
\text { system-wise } \\
\text { mortality }\end{array}$ & $2(22.22 \%)$ & $1(\mathbf{1 1 . 1 1 \% )}$ & $3(33.33 \%)$ & $3(33.33 \%)$ & - & $9(\mathbf{1 0 0 . 0 0 \%})$ \\
\hline \multicolumn{7}{|c|}{ Bacterial species isolated from different samples collected from kids } \\
\hline $\begin{array}{l}\text { Bacterial species } \\
\text { isolated }\end{array}$ & Intestine & Lungs & Tracheal swab & Heart blood & $\begin{array}{l}\text { Total number } \\
\text { of different } \\
\text { bacterial } \\
\text { species } \\
\text { isolated }\end{array}$ & $\begin{array}{l}\text { Percentage of } \\
\text { different bacterial } \\
\text { species isolated }\end{array}$ \\
\hline E. coli & 9 & 1 & 0 & 3 & 13 & 52.00 \\
\hline Klebsiella spp. & 5 & 0 & 0 & 0 & 5 & 20.00 \\
\hline Salmonella spp. & 0 & 1 & 0 & 0 & 1 & 04.00 \\
\hline Proteus spp. & 1 & 5 & 0 & 0 & 6 & 24.00 \\
\hline $\begin{array}{l}\text { Total number of } \\
\text { bacterial species } \\
\text { isolated from kids }\end{array}$ & $15(60.00 \%)$ & $7(28.00 \%)$ & $0(00.00 \%)$ & $3(12.00 \%)$ & $25(100.00 \%)$ & \\
\hline \multicolumn{7}{|c|}{ Faecal examination in diarrhoeic kids } \\
\hline $\begin{array}{l}\text { Fasciola } \\
\text { eggs }\end{array}$ & Trichuris eggs & Eimeria spp. & \multicolumn{2}{|l|}{ Mixed infection } & \multicolumn{2}{|c|}{ Negative sample } \\
\hline 1 & 1 & 4 & \multicolumn{2}{|c|}{$\begin{array}{l}1 \text { (Eimeria } \text { spp. + Fasciola eggs) } \\
1 \text { (Eimeria } \text { spp. + Trichuris eggs) }\end{array}$} & \multicolumn{2}{|l|}{2} \\
\hline \multicolumn{7}{|c|}{ Faecal examination in dead kids } \\
\hline Eimeria spp. & \multicolumn{2}{|c|}{ Mixed infection } & \multirow{2}{*}{\multicolumn{2}{|c|}{ Negative sample }} & \multicolumn{2}{|c|}{ Total number of cases } \\
\hline 3 & \multicolumn{2}{|c|}{1 (Eimeria spp. + Fasciola egg) } & & 5 & \multicolumn{2}{|l|}{9} \\
\hline
\end{tabular}

Table.2 Gross pathological changes observed during postmortem examination of kids

\begin{tabular}{|l|}
\hline Gross Changes \\
\\
\hline Congestion \\
\hline Haemorrhages \\
\hline Necrotic areas \\
\hline Consolidation \\
\hline Firmness and induration \\
\hline Exudate \\
\hline Enlargement \\
\hline Distension \\
\hline
\end{tabular}
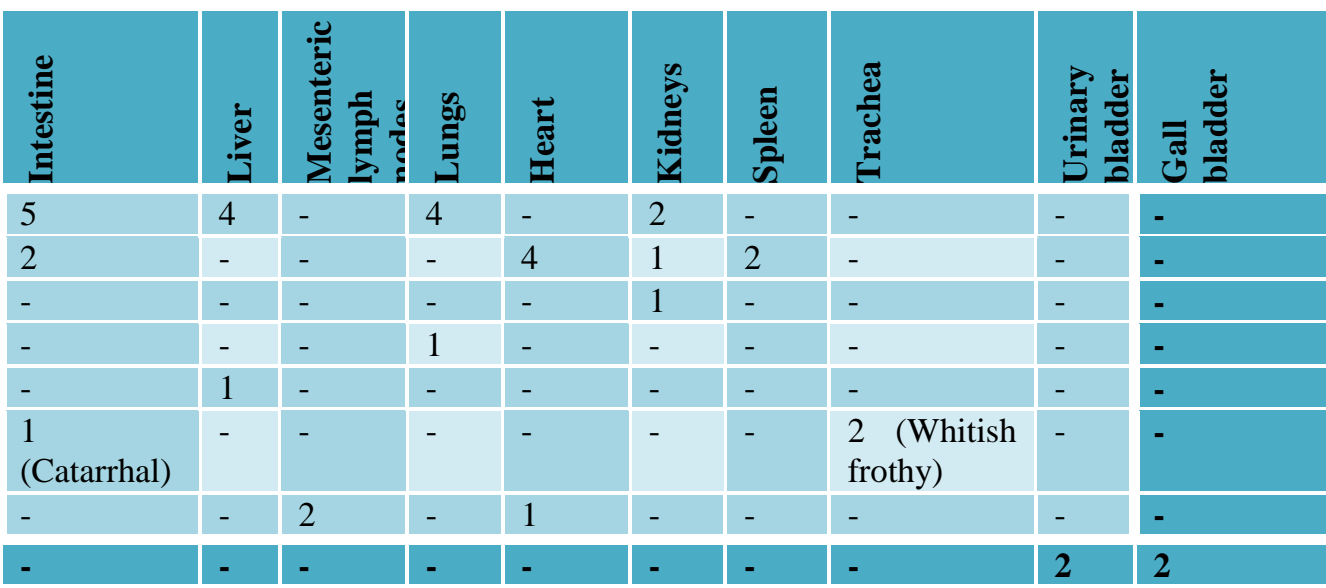


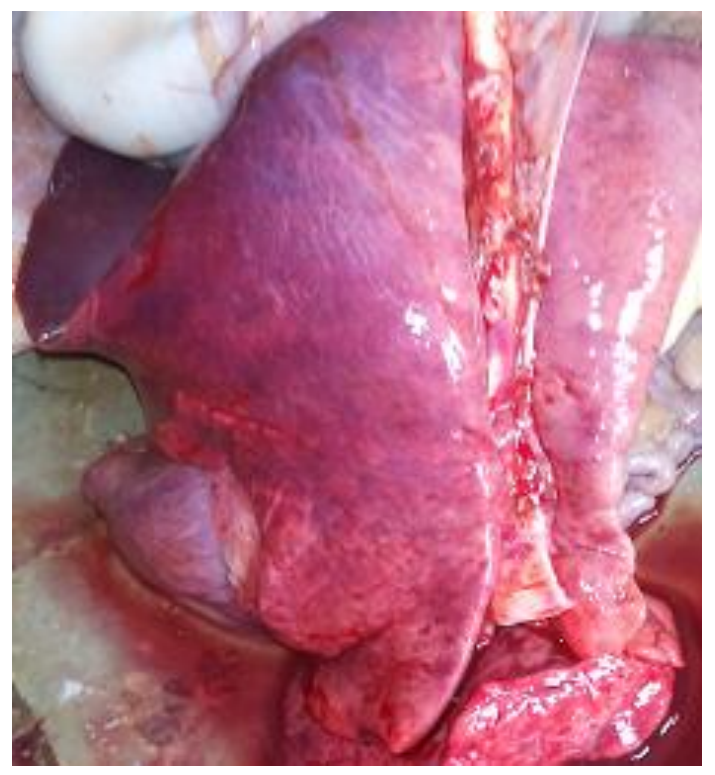

Fig. 1 Congested lungs (Kid, E. coliand Proteus spp.infection)

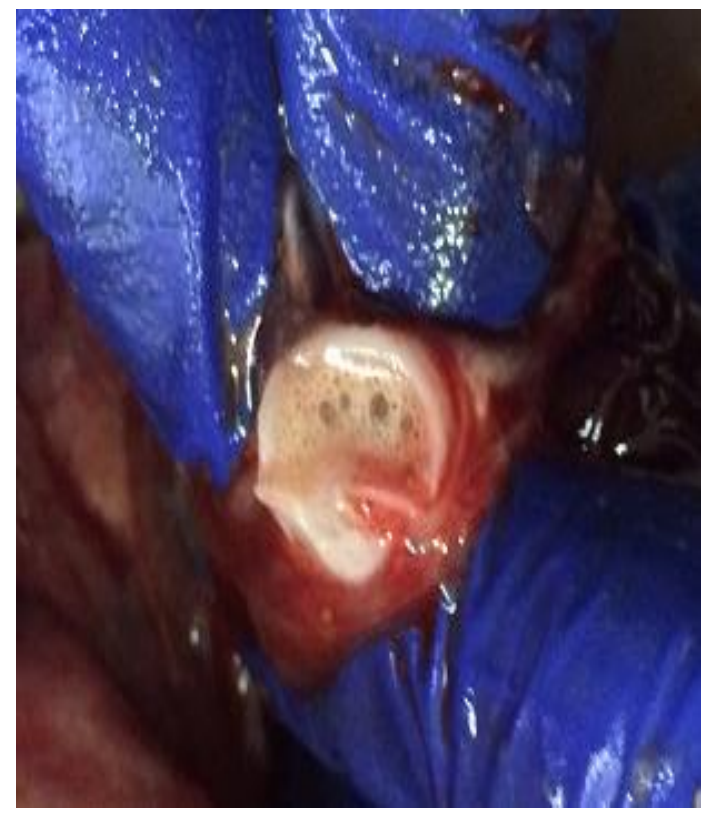

Fig. 3 Whitish frothy exudate in trachea (Kid, E.coli and Proteus spp.infection)

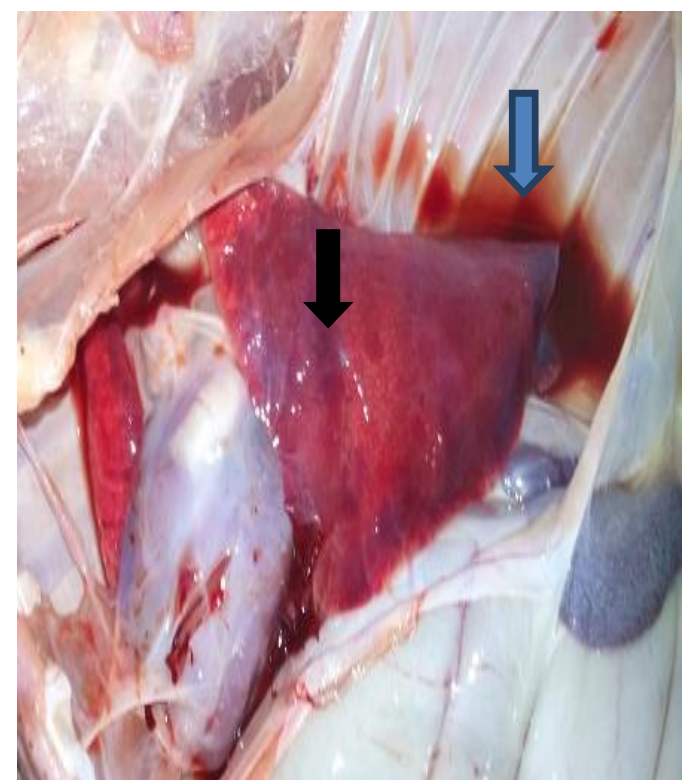

Fig. 2 Hydrothorax with serosanguinous fluid $(\vec{b})$ and congested lungs $(\vec{b})$ (Kid, E. coli

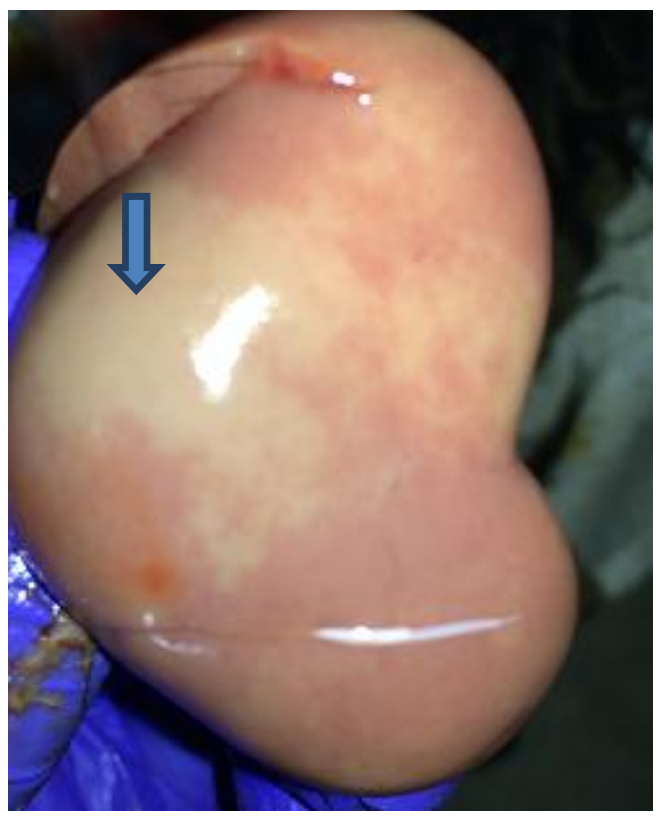

Fig. 4 Pale kidney showing presence of necrotic areas (Kid,Salmonella spp.infection) 


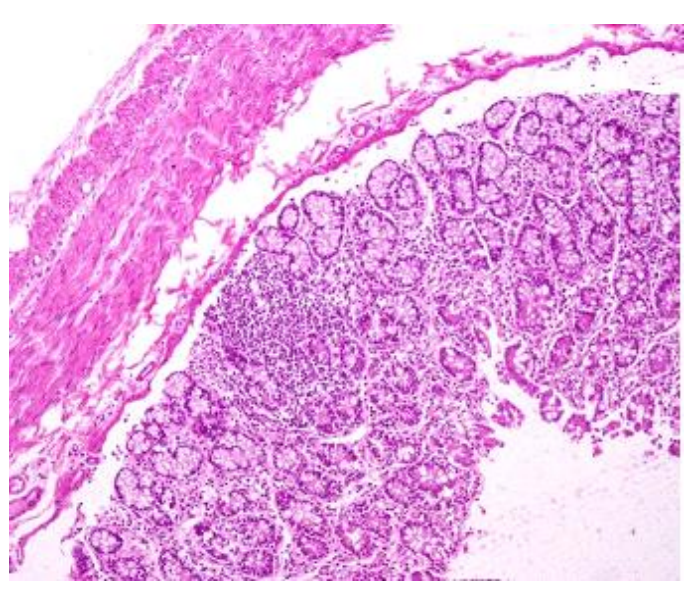

Fig.5 Intestine: Catarrhal enteritis characterized by goblet cell hyperplasia along with infiltration of leucocytes there by completely replacing the mucosal glands(Kid, $E$. coli and Klebsiella spp. infection) $H \& E \times 100$

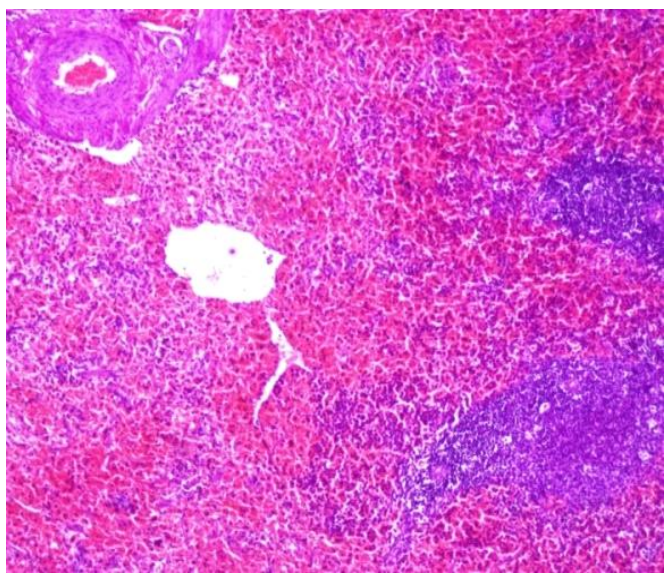

Fig. 6 Liver: Hepatitis characterised by focal area of necrosis of hepatocytes in parenchyma. Leucocytic cell infiltration (Kid, E. coli, Klebsiella spp. and Eimeria spp. infection) $H \& E X 100$

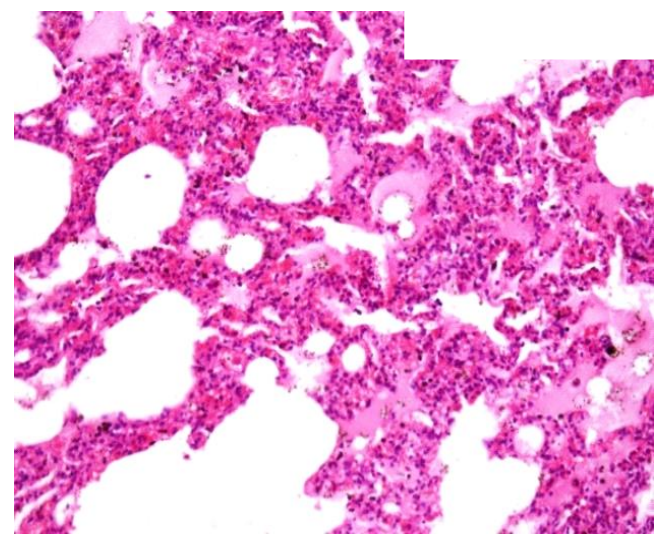

Fig.7 Lungs: Serous pneumonia characterised by presence of serous fluid in alveoli along with infiltration of leucocytes, Emphysema and conoested alveolar canillaries (Kid. $E$. 
E. coli was found highly resistant to tetracycline; Salmonella spp. to amoxyclav, tetracycline; Klebsiella spp. to amoxyclav, polymyxin B and ampicillin; Proteus spp. to $16.66 \%$ ) polymyxin B, amoxycillin, tetracycline and amoxyclav, co trimoxazole, ciprofloxacin. More or less similar results with respect to antimicrobial sensitivity resistance patterns have been reported previously by Blanco et al., (1996) and Abou-Zaid et al., (2000) in kids.

Examination of faecal samples of diarrhoeic/diseased kids revealed that Eimeria spp. was the major infection followed by Fasciola egg alone, Trichuris eggs alone, mixed infection of Eimeria spp. along with Fasciola eggs and Eimeria spp. along with Trichuris egg.

Examination of dead kids revealed that Eimeria spp. was the major infection followed by mixed infection of Eimeria spp. along with Fasciola egg. More or less similar observations were reported by Ibrahim et al., (2014) as they also reported Coccidian and Fasciola infection in kids.

In kids, mortality was influenced by age groups and suggesting that more care and attention need to be paid in age group of 1 to 3 months. Young ones of this group require adequate care and management such as feeding of colostrum, better health care and proper housing to avoid seasonal stresses. No mortality was seen in age group 3-6 months due to better management practices given to this age group. Sex-wise mortality was more in male as compared to females. System-wise mortality in young ones of kids was higher due to combined involvement of digestive system along with respiratory system followed by affections of digestive systems alone and respiratory system alone. Gastritis, enteritis, pneumo-enteritis, hepatitis and pneumonia were the main conditions encountered in kids. Different bacterial species isolated from young ones of kids were E. coli, Proteus spp., Klebsiella spp. and Salmonella spp. Maximum numbers of bacterial species were isolated from intestine followed by lungs and heart blood. Most of the bacterial species were highly sensitive to gentamycin and highly resistant to tetracycline in young ones of kids. Examination of faecal samples of diarrhoeic and dead kids revealed that Eimeria spp. was the major infection and faecal samples of dead kids revealed that Eimeria spp. was the major infection. Therefore, proper deworming should be done at early age of life and at proper timing.

\section{Acknowledgments}

The authors are highly thankful to Dean PGs, College of Veterinary Science and Animal Husbandry, Lala Lajpat Rai University of Veterinary and Animal Sciences, Hisar, India, for providing necessary funds and facilities to carry out the investigation.

\section{References}

Abou-Zaid, A., Eisa, M.I. and Diab, R.A. 2000. Bacterial causes of enteritis in neonatal lambs and kids. Vet. Med. J. Giza., 48(3): 469-473.

Alam, S., Singh, P.K. and Khan, B.U. 2008. Morphological studies and management of Beetal goats in its native tract. Indian J. Anim. Sci., 78(10): 1127-1130.

Bauer, A.W., Kirby, W.M.M., Sherris, J.C. and Truck, M. 1966. Antibiotic susceptibility testing by standardized single disc method. American J. Clin. Pathol., 45: 493.

Chowdhury, S.A., Bhuiyan, M.S. and Faruk, A.S. 2002. Rearing Black Bengal goat under semi-intensive management 1. Physiological and Reproductive Performances. Asian-Australasian J. Anim. Sci., 15(4): 477-484.

Cruickshank, R. and McCartney, J.E. 1965. Medical Microbiology: guide to the laboratory diagnosis and control of infection. $12^{\text {th }}$ ed. The English Language Books Society and Churchill living stone.

Dai, Y., X. Liu, M. Liu and Tao, J. 2006. Pathogenic effects of the coccidium Eimerianinakohlyakimovae in goats. Vet. Res. Commun., 30: 149-160 
Dohare, A.K., Singh, B., Bangar, Y., Prasad, S., Kumar, D. and Shakya, G. 2013. Influence of age, sex and season on morbidity and mortality pattern in goats under village conditions of Madhya Pradesh. Vet. World, 6(6): 329-331.

Ershaduzzaman, M., Rahman, M.M., Roy, B.K. and Chowdhury, S.A. 2007. Studies on the diseases and mortality pattern of goats under farm conditions and some factors affecting mortality and survival rates in Black Bengal kids. Bangladesh J. Vet. Med., 5(1\&2): 71-76.

Honhold, N. 2001.Final Report on Veterinary Epidemiology. Bangladesh Livestock Research Institute, Savar, Dhaka-1341, Bangladesh.

Husain, S.S., Islam. A.B.M. and Horst, P. 1995.Effect of different factors on preweaning survivability of Black Bengal kids.Small Rum. Res., 18: 1-5.

Ibrahim, N., Tefera, M., Mihreteab, B. and Alemu, S.2014. Prevalence of gastrointestinal parasites of small ruminants in and around Jimma Town, Western Ethiopia. ActaParasitol.Glob., 5(1): 12-18.

Khillare, B.S., Narladkar and Gangane, G.R. 2014. Histopathological and histochemical studies on naturally occurring coccidial infection in caprine of Marathawada region. Indian J. Vet. Pathol., 38(1): 18-21.

Luna, L.G. 1968. Manual of Histologic Staining Methods of the Armed Forces Institute of Pathology. $3^{\text {rd }}$ ed. McGraw Hill Book Company, New York.

Malik, C.P., Kanaujia, A.S., Balaine, D.S. and Rathi, S.S. 1990. Mortality pattern in Beetal and Black Bengal goats and their reciprocal crosses. Indian J. Anim. Sci., 60(2): 228232.

Norman, G. A. 1991. The potential of meat from goat. In: Developments in Meat Science
(Ed. R. A. Lawrie). Elsevier Applied Science, London. pp. 57-87.

Nwosu, C.O., P.P. Madu and Richards, W.S. 2007. Prevalence and seasonal changes in the population of gastrointestinal nematodes of small ruminants in the semiarid zone of North-Eastern Nigeria. Vet. Parasitol, 144: 118-124.

Patel, J.M., Patel, D.R., Mavadiya, S.V., Solanki, J.B., Vihol, P.D., Sharma, K.K., Trangadia, B.J. and Kalyani I.H. 2015. Clinicopathological investigation of an outbreak of peste des petits ruminants in small ruminants in South Gujarat, India. Indian J. Vet. Pathol., 39(1): 20-23.

Ramíirez-Bribiesca, J.E., Tortora, J.L., Hernández, L.M. and Huerta, M. 2001. Main causes of mortalities in dairy goat kids from the Mexican plateau. Small Rum. Res., 41(1): 77-80.

Sabapara, G.P. and Deshpande, S.B. 2010. Mortality Pattern in Surti goats under field condition. Vet. World, 3(4): 165-166.

Sharif, L., Obeidat, J. and Al-Ani, F. 2005. Risk factors for lamb and kid mortality in sheep and goat farms in Jordan. Bulgarian J. Vet. Med., 8(2): 99-108.

Sharma, S.K., Nagda, R.K., Kumar, U. and Khadda, B.S. 2007. Mortality pattern in Sirohi goats under field conditions. Indian J. Small Rum., 13(2): 210-212.

Som, T.L. and Bhattacharya, H.M. 1987. Lymphadenitis in sheep and goats. Indian Vet. Med. J., 11(4): 227-230.

Soulsby, E.J.L. 1982. Helminths, Arthropods and Protozoa of Domesticated animals. $7^{\text {th }}$ ed. Bailliere Tindall, East Sussex, UK.

Zaki, M.S., Nagwa, N.A., Shalaby, S.I. and Zatoon, E.M. 2010. Diarrhoea in neonatal baraki kids-goats. Life Sci. J., 7(3): 129132.

\section{How to cite this article:}

Sushma, V. Nehra, B.L. Jangir and Sharma, V. 2018. Aetio-Pathological Studies of Digestive and Respiratory Affections Affecting Kids. Int.J.Curr.Microbiol.App.Sci. 7(05): 180-188. doi: https://doi.org/10.20546/ijcmas.2018.705.023 